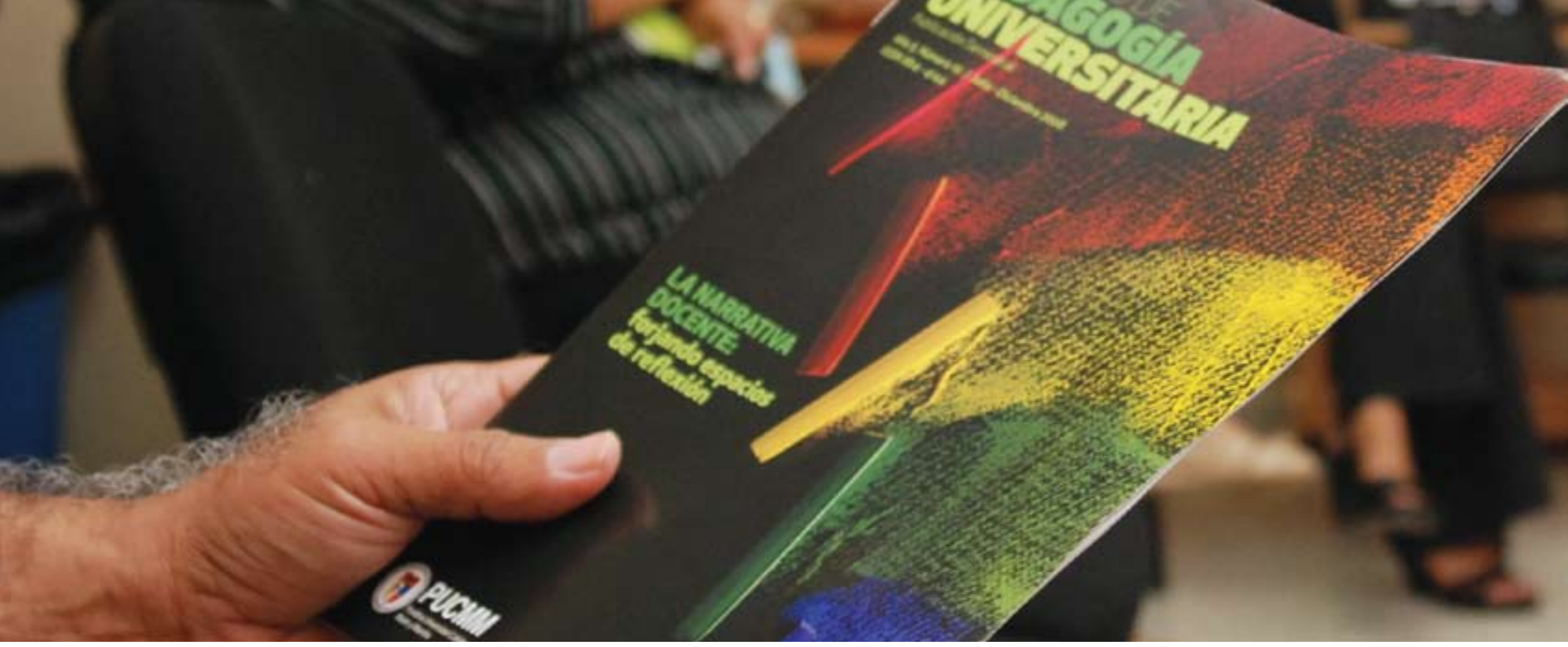

\title{
VOCES DE NUESTROS LECTORES
}

\section{Retroalimentación recibida desde la comunidad académica sobre el ejemplar anterior "La Narrativa Docente: forjando espacios de reflexión" correspondiente a Julio - Diciembre 2008}

\author{
Apreciada Marta:
}

Un saludo desde Mendoza. Recibí la revista. Se trata de un número con materiales que proponen de manera clarísima lo que significa la narración en el espacio de la educación. Ha sido un honor para mí participar en esa valiosa iniciativa.

Quedemos en comunicación para otros intercambios, tanto de materiales como de experiencias.

Con afecto,

\section{Daniel Prieto Castillo}

Articulista invitado, Universidad de Cuyo, Mendoza

\section{Estimada Marta, ¿qué tal? Espero que bien.}

Esta mañana me ha llegado el envío de los ejemplares de la revista. Muchísimas gracias. Ha quedado muy bien (jaunque si Pablo me lo hubiera dicho podría haber enviado una foto en "mejores condiciones"!). El número, en general, ha quedado muy interesante. Creo que tiene un muy buen nivel me parece riguroso, al mismo tiempo ágil y adecuado, y sobre todo tratando un tema novedoso de una forma audaz. Por tanto, no me queda más que daros mi enhorabuena.

Seguro que en cualquier otro momento podremos colaborar, ya sea en la revista como en la propia universidad. Un saludo muy cordial,

\section{Tomás Domingo Moratalla}

Articulista invitado, Universidad Complutense de Madrid

Valoro significativamente la última edición con el tema de La Narrativa Docente como eje central. Destaco las tres secciones más significativas para mí en esta entrega:

La primera, Ventanas Abiertas a la Pedagogía Universitaria, en la cual los escritores invitados exponen argumentos substanciales para incorporar la narrativa en nuestra cotidianidad como docentes.

La segunda, Ecos desde las Facultades, en el artículo de "La narrativa docente como transformadora de la práctica educativa", se motiva y presenta una guía sencilla y válida para reflexionar sobre nuestra práctica y elaborar un diario docente que permita sistematizar el proceso pedagógico, construyendo aportes para un desarrollo personal y profesional.

Finalmente, la sección Pasos y Huellas presenta cómo el proceso formativo a través de las diferentes modalidades de los programas relacionados a la Pedagogía Universitaria, ha incidido en la vida de profesores de la Universidad; los testimonios muestran la realidad de los docentes: sus orígenes, los aspectos inherentes a los múltiples roles que coexisten con la función de ser docente, así como los conflictos naturales que se dan en un departamento académico.

Gracias a todo el equipo por la entrega, dedicación y seguimiento para cada edición así como a los autores por compartir con la comunidad universitaria sus conocimientos y reflexiones.

\section{Roselys Arias Sirí}

Profesora de la Facultad de Ciencias Sociales y Administrativas, Recinto Santo Tomás de Aquino, PUCMM 